\section{Rates of Hospital-Acquired Influenza Due to the Pandemic H1N1 Virus in 2009, Compared with Seasonal Influenza}

To the Editor-As was reported recently in the journal by Shiley et al, ${ }^{1}$ it is important to investigate the differences in clinical and epidemiological characteristics between pandemic and seasonal influenza. However, is interesting to describe the differences in nosocomial transmission. Chile is a country with about 17 million people and had strong pandemic influenza during the winter season of 2009 (June-August). During the pandemic, 368,118 cases were registered, with a total of 1,622 serious cases that required hospitalization ( 9.6 cases per 100,000 inhabitants) and a total of 153 deaths ( 0.9 deaths per 100,000 inhabitants). ${ }^{2}$

For us it was also interesting to compare the number of cases of influenza due to the pandemic H1N1 strain with the number of cases of seasonal influenza among adults who required hospitalization in our center, Hospital Clínico Univ- ersidad Católica. This is a tertiary care teaching hospital in Santiago, which has nearly 500 beds and approximately 25,000 patient admissions per year. During a 9-week period (May 18th to July 19th, 2009), we prospectively collected data on 54 cases of pandemic $\mathrm{H} 1 \mathrm{~N} 1$ influenza that were confirmed by polymerase chain reaction, and we compared them with 95 proven cases of seasonal influenza $A$ in inpatients that had been registered prospectively during the influenza seasons of 1999 ( 55 cases) and 2004 ( 40 cases); during both these years, the $\mathrm{H} 3 \mathrm{~N} 2$ strain was the local predominant circulating influenza $A$ virus. ${ }^{3,4}$

During the 2009 pandemic H1N1 influenza season, all patients were managed in agreement with Chilean guidelines, using droplet and contact precautions and antiviral therapy with the neuraminidase inhibitors oseltamivir or zanamivir. Previously, during the 1999 and 2004 seasonal influenza seasons, use of droplet precautions and amantadine were our standard of care. Table 1 compares the demographic and clinical characteristics of patients with pandemic H1N1 influenza and those with seasonal influenza. Pandemic influenza affected fewer older patients. In fact, $31.5 \%$ of patients

TABLE 1. Comparison of Clinical and Epidemiological Characteristics of 54 Patients with 2009 Pandemic Influenza A(H1N1) Virus Infection and Those of 95 Patients with Seasonal Influenza in 1999 and 2004

\begin{tabular}{|c|c|c|c|}
\hline Characteristic & $\begin{array}{l}\text { Pandemic } \\
\text { influenza group } \\
(n=54)\end{array}$ & $\begin{array}{c}\text { Seasonal } \\
\text { influenza group } \\
(n=95)\end{array}$ & $P$ \\
\hline Age, years & $52.9 \pm 19.5$ & $63.2 \pm 21.5$ & .003 \\
\hline Male sex & $28(51.9)$ & $44(46.3)$ & .5 \\
\hline Comorbidities & $43(79.6)$ & $67(70.5)$ & .2 \\
\hline Pregnant & $4(7.4)$ & 0 & .02 \\
\hline Nosocomial acquisition & $14(25.9)$ & $12(12.6)$ & .04 \\
\hline Fever $\left(\right.$ temp. $\left.>38^{\circ} \mathrm{C}\right)$ & $32(59.3)$ & $74(77.9)$ & .02 \\
\hline Chills & $11(20.4)$ & $58(61.1)$ & $<.001$ \\
\hline Myalgias & $21(38.9)$ & $59(62.1)$ & .006 \\
\hline Cough & $42(77.7)$ & $89(93.7)$ & .004 \\
\hline Sputum production & $19(35.2)$ & $65(68.4)$ & $<.001$ \\
\hline Dyspnea & $27(50)$ & $46(48.4)$ & .8 \\
\hline Headache & $12(22.2)$ & $37(38.9)$ & .04 \\
\hline Vomiting & $2(3.7)$ & $18(18.9)$ & .01 \\
\hline Diarrhea & $2(3.7)$ & $10(10.5)$ & .2 \\
\hline Lung rales & $28(51.9)$ & $54(56.8)$ & .5 \\
\hline Wheezing & $18(33.3)$ & $48(50.5)$ & .04 \\
\hline WBC count, cells $/ \mathrm{mm}^{3}$ & $8,601 \pm 5,044$ & $9,734 \pm 4,247$ & .16 \\
\hline Bands & $3(5.6)$ & $54(56.8)$ & $<.001$ \\
\hline C-reactive protein level, $\mathrm{mg} / \mathrm{dL}^{\mathrm{a}}$ & $6.6 \pm 5.9$ & $9.4 \pm 6.5$ & .008 \\
\hline Pulmonary infiltrates & $20(37)$ & $22(23.2)$ & .07 \\
\hline Intensive or intermediate care unit admission & $26(48.1)$ & $24(25.3)$ & .006 \\
\hline Mortality & $2(3.7)$ & $1(1.1)$ & .6 \\
\hline
\end{tabular}

NoTE. Data are mean value \pm standard deviation or no. (\%) of patients, unless otherwise indicated. Temp, temperature; WBC, white blood cell.

a Normal value, $<1 \mathrm{mg} / \mathrm{dL}$. 
with pandemic H1N1 influenza were over 65 years old, compared with $68 \%$ of patients with seasonal influenza $(P<$ $.001)$. A large proportion of patients with chronic diseases and a relatively low number of immunocompromised subjects were seen in both groups. Pregnant women hospitalized with influenza were seen only during the $2009 \mathrm{H} 1 \mathrm{~N} 1$ influenza outbreak. There were twice as many cases of hospital-acquired H1N1 influenza as there were of seasonal influenza. With respect to clinical symptoms, fewer patients with pandemic H1N1 influenza had fever and bronchial obstruction, compared with patients with seasonal influenza; on the other hand, more cases of pneumonia, more admissions to an intensive or intermediate care unit, and more deaths were observed among the patients with H1N1 influenza.

Different published series, including that of Shiley et $\mathrm{al}^{1}$ and ours, have shown that the pandemic H1N1 influenza virus affected a younger age group. ${ }^{5,6}$ This could be related to exposure to another influenza A H1N1 virus similar to the one that caused the 1918 pandemic. $^{7}$

A very interesting observation is that a total of 14 patients (25.9\%) acquired the pandemic $\mathrm{H} 1 \mathrm{~N} 1$ influenza virus during hospitalization, with the onset of clinical manifestations occurring at a mean ( \pm standard deviation) of $16 \pm 16.7$ days after admission (range, 4-66 days). The high rate of hospitalacquired $\mathrm{H} 1 \mathrm{~N} 1$ influenza might reflect a higher rate of virus circulation (among patients, visitors and healthcare workers) and more transmissibility. In order to prevent nosocomial transmission of the pandemic H1Nl virus in 2009, a series of actions were applied at our hospital: a communication campaign oriented to relatives and friends, restriction of the presence of symptomatic visitors, placement of all patients with influenza under droplet and contact precautions, and initiation of antiviral treatment soon after sampling for suspected cases. Furthermore, planned hospitalizations for elective surgery were canceled during the 2 weeks of the pandemic's peak. Despite all these efforts, we observed more hospital-acquired cases than were observed during the 1999 and 2004 influenza seasons. It should be noted that the group of patients with hospital-acquired pandemic $\mathrm{H} 1 \mathrm{~N} 1$ influenza had higher rates of pneumonia, intensive care unit admission, and mortality. This confirms the complexity of nosocomial influenza ${ }^{8}$ and demonstrates the importance of early confirmed diagnosis and establishment of a strict infection control policy during the entire influenza outbreak season.

The frequency of pneumonia was greater among patients with pandemic $\mathrm{H} 1 \mathrm{~N} 1$ influenza than among those with seasonal influenza, although the difference was not statistically significant. In other series of hospitalized patients with pandemic H1N1 influenza in 2009, the frequency of radiologically documented unilobar or multilobar pneumonia was $60 \% .{ }^{5,9}$ These cases of pneumonia could be exclusively viral, on the basis of the negative bacteriological testing results. Furthermore, considering the current published data on viral pneumonia with unilobar or multilobar patterns, it may suggest that some cases of pneumonia in our series of patients could have been secondary to influenza. However, in clinical practice it was impossible to rule out a bacterial pneumonia and avoid administering antibacterial therapy for severely ill individuals.

The differences observed between influenza due to the pandemic $\mathrm{H} 1 \mathrm{~N} 1$ virus and seasonal influenza could be explained by the different patterns of infection of the H1N1 and H3N2 viruses. Kelly et $\mathrm{al}^{10}$ compared seasonal cases of influenza $\mathrm{A}$ $\mathrm{H} 1 \mathrm{~N} 1$ with cases of influenza due to pandemic $\mathrm{H} 1 \mathrm{~N} 1$ virus of swine origin and showed that both infections affected predominantly younger people. It is necessary to have more information to better understand the differences between novel $\mathrm{H} 1 \mathrm{~N} 1$ virus and seasonal $\mathrm{H} 1 \mathrm{~N} 1$ or $\mathrm{H} 3 \mathrm{~N} 2$ viruses.

In summary, our comparison of pandemic H1N1 virus infection with seasonal influenza infection in hospitalized adults showed that H1N1 infection affected predominantly the patients who were in a younger age group or pregnant; that the group with $\mathrm{H} 1 \mathrm{~N} 1$ influenza had a similar rate of comorbidities, a lower rate of severe influenza symptoms and significant laboratory findings, and a higher frequency of intensive care admission, pneumonia, and death; and that there was an elevated rate of nosocomial acquisition despite the implementation of infection control measures.

\section{Ricardo Rabagliati, MD; ${ }^{1}$ Jaime Labarca, $\mathrm{MD} ;{ }^{1}$ Leonardo Siri, MD; ${ }^{1}$ Carlos M. Perez, MD; ${ }^{1}$ Marcela Ferrés, $\mathbf{M D}^{2,3}$}

Affiliations: 1. Department of Internal Medicine, School of Medicine, Pontificia Universidad Católica de Chile, Santiago, Chile; 2. Department of Pediatrics, School of Medicine, Pontificia Universidad Catolica de Chile, Santiago, Chile; 3. Laboratory of Molecular Virology and Infectious Diseases, School of Medicine, Pontificia Universidad Católica de Chile, Santiago, Chile. Address reprint requests to Ricardo Rabagliati, MD, Department of Internal Medicine, Pontificia Universidad Católica de Chile, Lira 63, postal code 8330023, Santiago, Chile (rabagli@med.puc.cl).

(C) 2011 by the Society for Healthcare Epidemiology of America. All rights reserved. 0899-823X/2011/3202-0019\$15.00. DOI: $10.1086 / 657913$

\section{REFER E NCES}

1. Shiley KT, Nadolski G, Mickus T, Fishman NO, Lautenbach E. Differences in the epidemiological characteristics and clinical outcomes of pandemic (H1N1) 2009 Influenza, compared with seasonal influenza. Infect Control Hosp Epidemiol 2010;31:676-682.

2. Ministry of Health of Chile. Pandemic influenza (H1N1) 2009: final report. January 13, 2010. http://www.pandemia.cl/templates/ pandemia/documentos/Informe_13_enero.pdf. Accessed August 31, 2010.

3. Rabagliati R, Benitez R, Fernandez A, et al. Influenza-A as etiology of fever and respiratory insufficiency in adults hospitalized during an outbreak in Chile. Rev Med Chile 2004;132:317-324.

4. Rabagliati BR, Serri VM, Perret PC, et al. Clinical and epidemiological characteristics of respiratory virus infections among adults hospitalized during 2004 influenza season. Rev Chil Infect 2006;23:111-117. 
5. Jain S, Kamimoto L, Bramley AM, et al. Hospitalized patients with $2009 \mathrm{H} 1 \mathrm{~N} 1$ influenza in the United States, April-June 2009. N Engl J Med 2009;361:1935-1944.

6. Human infection with pandemic A (H1N1) 2009 influenza virus: clinical observations in hospitalized patients, Americas, July 2009-update. Wkly Epidemiol Rec 2009;84:305-308.

7. Hancock K, Veguilla V, Lu X, et al. Cross-reactive antibody responses to the 2009 pandemic H1N1 influenza virus. $N$ Engl J Med 2009;361:1945-1952.

8. Salgado CD, Farr BM, Hall KK, Hayden FG. Influenza in the acute hospital setting. Lancet Infect Dis 2002;2:145-155.
9. Jamieson DJ, Honein MA, Rasmussen SA, et al. H1N1 2009 influenza virus infection during pregnancy in the USA. Lancet 2009;374:451-458.

10. Kelly H, Grant K, Williams S, Smith D. H1N1 swine origin influenza infection in the United States and Europe in 2009 may be similar to H1N1 seasonal influenza infection in two Australian states in 2007 and 2008. Influenza Other Respi Viruses 2009; $3: 183-188$. 